\title{
EL FAMOSÍSIMO REINO DE ANDALUCÍA: Representación y descripción del espacio andaluz (siglos XVI-XVIII) ${ }^{1}$
}

\author{
Manuel Peña Díaz \\ UNiversidad de Córdoba
}

\section{RESUMEN}

Este artículo nos habla sobre la configuración tardía de la región de Andalucía, tal como la conocemos hoy, proceso que culminará en la segunda mitad del XVIII. Rastrea, particularmente, su configuración territorial, a través de un estudio minucioso de la cartografía de la región durante el siglo XVII. Describe el proceso de mitificación del territorio a partir de elementos culturales tales como la civilización tartésica, la colonización romana, la presencia musulmana y la reconquista cristiana.

PALABRAS CLAVE: Historia de Andalucía, Historia Moderna, cartografía, siglo XVII.

\section{ABSTRACT}

This article explains the late settings of the Andalusia region, as we know it today. This process ended in the second half of XVIII. It tracks, particularly its territorial configuration, through a detailed study of the cartography of the region during the seventeenth century. It describes the process of mystification of territory from such cultural elements as Tartessian civilization, the Roman colonization, the presence of Muslims and the Christian reconquest.

KEY WORDS: Andalucia History, Modern History, Cartography, XVII century.

\footnotetext{
1 Este estudio se integra en el marco del Proyecto de Investigación Tradiciones y conflictos. Historia cultural de la vida cotidiana en el mundo hispánico (siglos XVI-XVIII) (HAR2008-01406) financiado por el Ministerio de Ciencia e Innovación
} 
"El día 4 de noviembre por la mañana salimos de Mairena, y andadas cuatro leguas llegamos a Sevilla, ciudad del famosísimo reino de Andalucía”. De ese modo calificaba esta tierra el alemán Jerónimo Münzer en 1494² tan conocida en Europa por ser la última frontera de la cristiandad. El término genérico de Andalucía procede del siglo XIII, tras la conquista de toda el área bética por Fernando III, y su distribución en tres reinos: Sevilla, Jaén y Córdoba. El cese de la primera repoblación hacia 1275 -ocasionado por una menor disponibilidad demográfica castellana-, el inicio de las guerras contra meriníes y granadinos, unido a las luchas políticas internas de Castilla, favorecieron la fijación de una frontera estable ${ }^{3}$. El nuevo territorio andaluz quedó articulado en tres espacios: Sierra Morena, la depresión del Guadalquivir y las cordilleras béticas.

Los historiadores han demostrado como la rapidez de la conquista y primera colonización y el intenso aprovechamiento de la estructura económica anterior, aunque cambiasen los pobladores, explican el porqué Andalucía continuó siendo una región con una actividad económica importante, propia y autónoma. Ello no mengua el decisivo impacto socio-económico y cultural de las repoblaciones medievales y modernas, sino que reafirma la peculiaridad andaluza en la que se mixtificaron cambios y continuidades, en un continuo proceso que cubrió casi medio milenio desde el siglo XIII. Ni siquiera hubo homogeneidad en esta dinámica. Por ejemplo, mientras la Alta Andalucía tenía aspectos más similares al carácter de dependencia y de periferia que tenía La Mancha, Sevilla se reconvirtió en la cabeza del comercio regional y exterior del Sur de Castilla ${ }^{4}$.

Las divisiones eclesiásticas son otra muestra de las diferencias internas y las distintas dependencias externas. Los obispados de Córdoba y Baeza-Jaén fueron sufragáneos del arzobispado de Toledo, cuyo titular era además señor del Adelantamiento de Cazorla. La archidiócesis de Sevilla fue exenta, y de ella dependió la diócesis de Cádiz. No hubo una provincia eclesiástica de Andalucía. Otras divisiones administrativas (señoriales, inquisitoriales, militares, municipales...) se fueron desarrollando y superponiendo durante los siglos XVI y XVII, dando lugar a una compleja red de distintas jurisdicciones que, en muchas ocasiones, colisionaron.

\footnotetext{
2 Cit. GARCÍA MERCADAL, José (recop.): Viajes de extranjeros por España y Portugal : desde los tiempos más remotos hasta comienzos del siglo XX (VEEP), Salamanca, Junta de Castilla y León, 1999, vol. I, p. 347.

3 Manuel González señala que desde esos primeros años del reinado de Alfonso X, Andalucía es denominada como la Frontera, pero su unidad es perceptible sobre todo en la institución de nuevo cargos como "el Adelantado Mayor cuyas competencias (como las de otros funcionarios tales como el Notario Mayor o los Alcaldes de Andalucía) se extienden por toda la región dando fe de su carácter unitario", GONZÁLEZ, Manuel: "Andalucía Bética", en J. A. García de Córtazar y otros, Organización social del espacio en la España medieval. La Corona de Castilla en los siglos VIII al XV, Barcelona, Ariel, 1985, pp. 163-194, p. 187.

4 Entre los numerosos estudios dedicados a este proceso destacan los de LADERO QUESADA, Miguel Ángel: Andalucía a fines de la Edad Media. Estructuras. Valores. Sucesos, Cádiz, Universidad de Cádiz, 1999 y "Sobre la génesis medieval de la identidad andaluza", en Los mudéjares de Castilla y otros estudios de historia medieval andaluza, Granada, Universidad, 1989, pp. 221-256.
} 


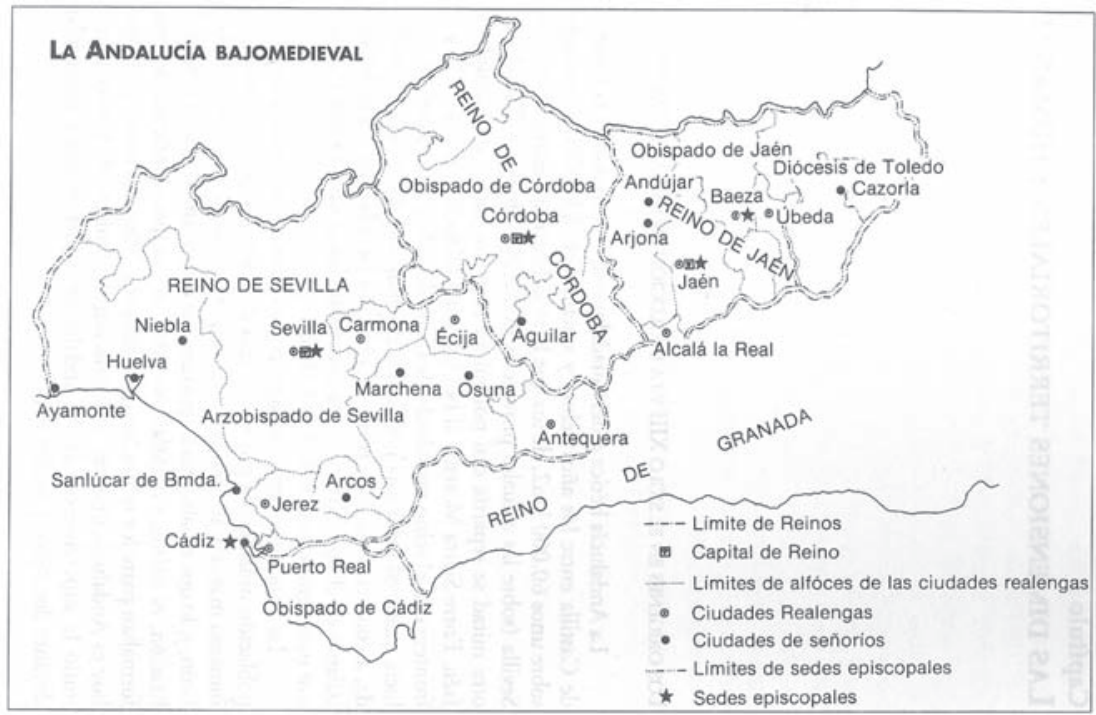

Fuente: M. A. Ladero Quesada, Andalucía a fines de la Edad Media...

En principio, el espacio andaluz se definió por composición castellana y por oposición a Granada. Ni siquiera los Reyes Católicos después de 1492 pretendieron, como afirma Domínguez Ortiz, "realizar la unidad institucional con los otros reinos andaluces, no sólo porque el concepto de unidad andaluza les era extraño, sino que trataban de establecer su autoridad sobre nuevas bases en el territorio conquistado"5. No obstante, existe una percepción generalizada entre los historiadores -y difundida en los libros de Historia de Andalucía- sobre la extensión de los límites de Andalucía a los cuatro reinos desde 1492 y bajo el concepto "reunificación" participación de la Andalucía fernandina en la conquista y la consecuencia unificadora de los procesos de repoblación del reino de Granada, realizados a fines del siglo XV y la segunda mitad del XVI con habitantes del valle del Guadalquivir. Antonio Luis Cortés señala, sin embargo, que no será hasta la segunda mitad del siglo XVIII cuando se aplique este término unitario al conjunto de los territorios de la actual Andalucía. Pero una visión es la externa o la administrativa y otra la interiorizada por los andaluces. Así Cortés Peña sugiere que "con anterioridad a la centuria decimonónica difícilmente podían percibirse los habitantes del sur de España como pertenecientes a una entidad común con caracteres diferentes a sus vecinos murcianos, manchegos o extremeños". Esta unidad espacial y humana sería consecuencia, en primer lugar, de una visión externa. Serían los viajeros románticos extranjeros quienes, con una imagen cargada de exotismos orientales, realizaran la primera "invención de Andalucía"7.

5 DOMÍNGUEZ ORTIZ, Antonio: "Discurso de clausura" en M. A. Ladero Quesada (ed.), La incorporación de Granada a la Corona de Castilla, Granada, Diputación, p. 329.

6 Véase por ejemplo MORENO ALONSO, Manuel: Historia de Andalucía, Córdoba, Cajasur, 1995, pp. 422 y ss. 7 CORTÉS PEÑA, Antonio Luis: "Nacionalismo/regionalismo andaluz, ¿una invención de laboratorio?", Historia Social, 40 (2001), pp. 140-141 y GONZÁLEZ ALCANTUD, José Antonio: “Andalucía: invención del país y realidad etnográfica", HAFO, 8 (1992), p. 8. 
Bartolomé Yun, no sin muchas prevenciones, sitúa en el período 1492-1652 pasos importantes "en la formación de Andalucía con una cierta personalidad propia y común al conjunto de la región". Su propuesta es comparar dicho proceso con el reforzamiento de una "comunidad imaginada" en el sentido de Benedict Anderson". Las representaciones colectivas sobre las que se construirían la supuesta identidad regional -con los límites de la Andalucía actual- incidirían en aspectos como el habla o la historia, cuyas propuestas y consiguientes percepciones difícilmente salieron fuera de círculos cultos. El mejor ejemplo para Yun es Gonzalo Argote de Molina, quien se propuso en su Nobleza de Andalucía (Sevilla, 1588): "escribir historia de la Antigüedad de las ciudades, villas y lugares de los Reinos de Andalucía y de los linajes nobles que la poblaron juntamente con sus hazañas". ¿De qué Andalucía? Granada no entró nunca en sus previsiones. En realidad en ese libro sólo está el Reino de Jaén, nunca se escribieron los de Córdoba y Sevilla, o se perdieron los manuscritos o no los llegó a escribir. La Andalucía de Argote era la misma que las de sus coetáneos: una parte de la Bética, resultado de las conquistas fernandinas. Aunque los límites geográficos de aquella Andalucía no fueron siempre los mismos, ni siquiera el peso de una época u otra de su historia tuvo la misma importancia.

\section{La historia y la exaltación patricia}

El interés por la Hispania romana -y en concreto por la Bética- aparece en la historiografía andalusí de la segunda mitad del siglo X. La obra del cordobés Ahmad al-Razi fue el fundamento de toda la historiografía cristiana hasta el siglo XIX. La reivindicación más extensa del pasado romano vendrá con la gran crónica general de Alfonso X el Sabio9. La colonización romana del Guadalquivir, preludio del esplendor de la Bética, era vista como el precedente de la conquista castellana de Fernando III y del propio Alfonso X. La herencia romana era aún más evidente para Lucio Marineo Sículo, quien consideraba a los castellanos como los legítimos herederos de los jefes militares que los romanos dejaron al frente de los castillos. El río Betis era el eje central por el que habían discurrido los distintos pueblos, pero para Marineo Sículo no había duda: "Por lo cual, los puentes y fortalezas y otras muchas cosas famosas que de los antiguos se hallan en España, no a Hércules más por cierto a los romanos, y principalmente a Julio César, se pueden atribuir"10. El debate estaba abierto. Los tiempos -como recordó Fernando Gascó- eran propicios para la reivindicación del pasado clásico con una mixtificación de fundadores divinos o no, de antigüedad y linaje, de griegos o bárbaros, de lo bíblico con lo clásico ${ }^{11}$. Fuera Hércules, Tubal o romanos, lo que estaba claro era que los andaluces

\footnotetext{
8 YUN, Bartolomé: “Andalucía, entre Europa, América y el mundo mediterráneo”, en A. Prieto (dir.), Historia de Andalucía, Barcelona-Sevilla, Planeta-Fundación José Manuel Lara, 2006, vol. VI, pp. 84-87.

9 GOZÁlBES CRAVIOTO, Enrique: El descubrimiento de la Historia Antigua en Andalucía, Málaga, Sarriá, 2000, pp. 25-28.

10 MARINEO SÍCULO, Lucio: De las cosas memorables de España, Alcalá de Henares, 1530 (1ª ed. latín, c.1496) (cit. GOZÁLBES, E: op. cit. p. 38).

11 GASCÓ, Fernando: "Historiadores, falsarios y estudiosos de las antigüedades andaluzas", en J. Beltrán y F. Gascó (eds.), La Antigüedad como argumento. Historiografía de arqueología e historia antigua en Andalucía, Sevilla, s.e., 1993, pp. 9-28
} 
no descendían de bárbaros anónimos. Las representaciones de Hércules -uno o trino- en la primera mitad del siglo XVI fueron tan numerosas y diversas (pinturas, escudos, tapices, portadas de libros...) que su vínculo con la Andalucía bética terminó por ser incuestionable, y "no sólo como héroe de fuerza sobrehumana -escribió Domínguez Ortiz-, sino como emblema de ciencias y virtudes, educador de pueblos. La Bética fue el teatro predilecto de sus actividades". Había fundado Sevilla y fue el gran protagonista en Cádiz y del distanciamiento cultural respecto a África. La apertura del Atlántico confirmó su eternidad, sus columnas con el retocado lema (Plus Ultra) -acuñadas en monedas- se convirtieron en el emblema de la proyección imperial española ${ }^{12}$.

La fabulación de Annio de Viterbo deformó aún más esta visión del pasado. La lista de reyes del supuesto Beroso arrancaban de Hércules y de Hispán y la Andalucía pre-romana enriquecía la historia del sur, la visión indígena tomaba fuerza ${ }^{13}$. A pesar de su divulgación, fueron los mitos y las fuentes literarias de la antigüedad los que se convirtieron en argumentos para la invención de símbolos vinculados con la Andalucía del Renacimiento. Y en esa recopilación de autoridades, los Ptolomeo, Estrabón, Tito Livio, Cayo Plinio, Herodoto,... seguían siendo fundamentales. La aportación de Florián de Ocampo en su Crónica General de España $(1543,1553)$ fue clave en este proceso, al desarrollar el concepto del reino de Tartessos siguiendo textos griegos, hasta el punto que según Gozalbes "con Ocampo nacían los "andaluces" como pueblo milenario y civilizado, y Tartessos como su gran mito histórico" ${ }^{14}$. El modelo de Historia de España que generó el cronista de Carlos I, tuvo su continuidad con Ambrosio de Morales y con Juan de Mariana, quien se convertirá en referente historiográfico hasta mediados del siglo XIX. La Andalucía primitiva, previa a la invasión fenicia, estaba en los orígenes de España. El nieto de Noé, Tubal, llegaba a Andalucía en 2163 a. C. El relato bíblico de la tradición bajo-medieval adquiría carta de naturaleza y dotaba a Andalucía de la categoría de primera región poblada de Occidente y, por tanto, de un espacio donde se desarrolló Tartessos, la primera civilización clásica anterior a Grecia y Roma, y cuna de la monarquía hispana (Gargoris, Habis y Argantonio) ${ }^{15}$. El arraigo de la tesis del papel clave de Andalucía en el nacimiento de España se difundió con rapidez entre las elites culturales andaluzas. Por ejemplo, Agustín de Horozco, que halló errores de bulto en la obra de Ocampo ${ }^{16}$, consideraba a los gaditanos-eritreos como los tartesios-andalucesespañoles que recibieron, sufrieron y se enfrentaron a "feníces, tiros y sidones". Juan

12 DOMÍNGUEZ ORTIZ, Antonio: "La historiografía local andaluza en el siglo XVII", en Los extranjeros en la vida española durante el siglo XVII y otros artículos, Sevilla, Diputación, 1996, pp. 458-459.

13 CARO BAROJA, Julio: Las falsificaciones de la historia (en relación con la de España), Barcelona, Seix Barral, 1991, pp. 49 y ss.

14 GOZALBES, E.: op. cit., p. 40.

15 El estudio más completo sobre este proceso de invención y su evolución en la historiografía española es la obra de ÁLVAREZ MARTÍ-AGUILAR, Manuel: Tarteso. La construcción de un mito en la historiografía española, Málaga, CEDMA, 2005.

16 "El maestro Florián de Ocampo dice en sus Antigüedades de España que Gerión, rey de ella, tuvo una hija llamada Eritrea, y casi se inclina a entender que de ella se llamó Eritrea esta isla [Cádiz]; mas yo téngolo por engaño, y por lo más cierto lo que se ha dicho de los primeros pobladores eritreos, si cosa cierta hay en lo que escriben de aquéllas tan largas y atrasadas edades, sobre que cae tanta duda, que ni se puede afirmar todo, ni dejar de creer algo, y eso con harto escrúpulo". HOROZCO, Agustín de: Historia de la Ciudad de Cádiz (1598), ed. A. Morgado, Cádiz, Universidad, 2001, p. 6. 
Bautista Suárez de Salazar (Grandeza y antigüedades de la isla y ciudad de Cádiz, 1610) también situó en la ciudad la antigua Tartessos. La depuración de las fuentes clásicas y de las falsas relaciones de los cronicones se produciría con la obra de Gaspar Ibáñez de Segovia (Cádiz phenicia, 1687). La fiebre tartésica fue compartida por otros eruditos que se afanaron por hallar la ubicación exacta del símbolo del sur civilizado y rico. La identificación entre el Tartessos de las fuentes grecolatinas con el Tarsis bíblico a fines del siglo XVI impulsó aún más este ansia localista. A Cádiz se sumaba la reivindicación de Jerez, de Sanlúcar de Barrameda, Rota, Medina Sidonia, Tarifa, Sanlúcar la Mayor,...

Desde mediados del siglo XVI y durante la siguiente centuria, el coleccionismo arqueológico ayudó mucho a la fiebre tartésica. El entusiasmo por los vestigios aún visibles favoreció la construcción de estrechos lazos entre la Andalucía del Siglo de Oro y la antigüedad. De cualquier modo, y aunque fuera una consecuencia de la invasión romana que sometió a los españoles, la Bética era el pilar fundamental en el que sustentaban a las investigaciones de los cordobeses Juan Fernández Franco (Memorial de los nombres de los lugares de la antigua Bethica) o Ambrosio de Morales (Antigüedades de las ciudades de España, 1577), pioneros en esos estudios. El mejor canto a las excelencias de la Bética, a Hispalis y al territorio de su Chancillería lo realizó Rodrigo Caro. Alabanzas que dieron lugar a conocidas polémicas sobre la capitalidad de la Bética y a otras sobre míticas y arriesgadas ubicaciones. La acertada reivindicación de Córdoba como capital de la Bética la realizaron Martín de Roa (Antiguo principado de Córdova en la España ulterior o andaluz, 1617 y 1636) y Pedro Díaz de Ribas (Antigüedades y excelencias de Córdova, 1627). Los estudiosos jienenses también vincularon su pasado con el esplendor bético, especialmente Francisco de Rus Puerta (Corografía antigua y moderna del reino y obispado de Jaén, c. 1646) quien localizó las urbes romanas en ese reino ${ }^{17}$.

A pesar del indigenismo y del goticismo historiográfico dominante, entre los humanistas andaluces tuvo una enorme importancia y fue un pozo de inspiración el legado material de la Bética romana. Nebrija, Juan de Mal Lara, Pedro de Mexía, Fernando de Herrera, Francisco Pacheco, Rodrigo Caro, Pedro Espinosa, entre otros, exaltaron literariamente con éxito la herencia de la antigüedad clásica. La elaboración de numerosas historias locales, en la segunda mitad del siglo XVI y durante la siguiente centuria, acentuaron aún más este vínculo que dignificaba los orígenes de Andalucía, especialmente de su nobleza ${ }^{18}$.

La característica común de estas historias de villas y ciudades andaluzas fue la mixtificación de lo religioso y lo profano, de lo verdadero y lo falso, con una profusa reelaboración de la mitología clásica. Estas historias nutrieron lo que se ha denominado el género corográfico, fusión de crónica urbana y laudatio humanística. Kagan ha señalado las principales características de estos textos: "Defender, glorificar, celebrar: las obras corográficas no eran historias strictu sensu, sino alabanzas patrióticas hechas

17 Sobre esta recuperación véase la obra colectiva El rescate de la Antigüedad clásica en Andalucía, Sevilla, Focus-Abengoa, 2009, y en concreto el estudio de Fernando Wulff "Qué hacer con Roma. Historia, Historiografía, Andalucía", pp. 81-93.

18 En esa larga nómina de historias de ciudades andaluzas encontramos otras obras dedicadas a Cádiz de fray Jerónimo de la Concepción; a Sevilla de Morgado y de Peraza, entre otros; a Alcalá de Guadaíra de Monroy; a Andújar de Terrones y de Villar; a Antequera, de Espinosa y de Tejada; a Carmona de Arellano; a Jerez de fray Esteban Rallón,... 
para señalar, a través de la geografía y las historia las excelencias y las características de cada lugar"19.

En las historias nobiliarias, de villas y ciudades el énfasis se ponía en la Reconquista, sin olvidarse del rescate de la época prerromana y romana, y puntualmente de manera fugaz, de la islámica. En estas historias, escritas con el objeto de construir o inventar el pasado aristocrático-nobiliario de importantes familias, Andalucía era el escenario, el paisaje y lugar de sus hazañas, y tenía unos límites más o menos claros. La comunidad imaginada era la casa nobiliaria ubicada en las correspondientes ciudades y villas con sus ilustres mártires y patricios. Una comunidad que necesitaba de Andalucía, de su espacio y de su devenir histórico.

En el seno de la monarquía y sus posesiones, la colectividad andaluza se definía como local o de linaje. El argumento central era el éxito de la conquista y repoblación del siglo XIII, una reconstrucción religiosa y aristocrática del pasado. Su representación caló entre las elites de la sociedad andaluza moderna. Aunque el uso de la historia en el reino de Granada se hacía con las mismas herramientas y objetivos, esta práctica carecía de varias representaciones históricas que sí tenía la Baja Andalucía. En primer lugar, los orígenes colectivos entroncados con la civilización tartésica y el imaginario mitológico grecorromano; y en segundo lugar, la concreción de dicha representación en Fernando III.

En 1634 Pedro de Texeira resumió en las portadas interiores la pertenencia e identificación de los territorios del sur de España. En el reino de Andalucía (Sevilla, Córdoba y Jaén) es Fernando III quien focaliza la atención; la fidelidad al rey, como referente histórico y cultural. Y en la portada de los mapas del reino de Granada la corona regia se sitúa sobre el símbolo del fruto, y sin anotar el nombre del territorio ${ }^{20}$.
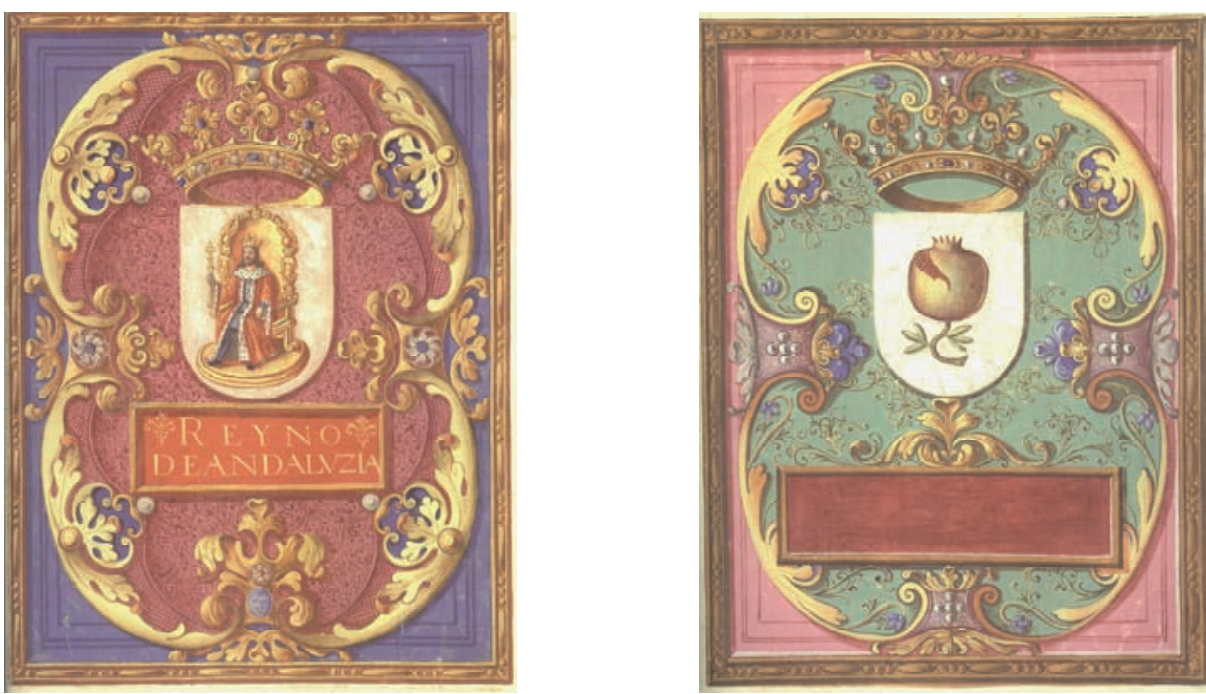

19 KAGAN, Richard L.: "La corografía en la Castilla moderna. Género, Historia, Nación”, Studia Historica. Historia Moderna, XIII (1995), p. 55.

20 PEREDA, Felipe y MARÍAS, Fernando (eds.), El Atlas del Rey Planeta. La "Descripción de España y de las costas y puertos de sus reinos" de Pedro de Texeira (1634), Madrid, Nerea, 2003 
Cierto es que la Andalucía de los siglos XVI y XVII careció de una historia regional como las que se publicaron sobre Cataluña (Pujades 1609), Asturias (Carvallo 1695), Navarra (Moret 1684-1715), Mallorca (Dameto 1632) o Valencia (Escolano 1610). Las referencias históricas a ese espacio común bético son limitadas y, en ocasiones, cargadas de rivalidad. Así sucedió con la obra de fray Jerónimo de la Concepción (Emporio de el Orbe. Cádiz Ilustrada, Amsterdam, 1690). No sólo porque el ayuntamiento gaditano enviase cincuenta ejemplares a los consejeros en la Corte para defender que, en lugar de Sevilla, Cádiz debía ser la sede del monopolio del comercio con Indias ${ }^{21}$, también porque el autor se extendía en sus críticas a la capital hispalense y a Rodrigo Caro, como su historiador más representativo. Un ejemplo: "No sé en que hayan ofendido los Gaditanos a Caro, que tan caro le cuestan sus alabanzas, y que por defender a Sevilla, quiera traspasar sus lunares a Cádiz. Quede pues firme, que no Cádiz; sino Sevilla con las demás ciudades, que refieren las historias, fueron las conjuradas contra Julio César" ${ }^{22}$. Caro también había reaccionado en su momento cuando Roa pretendió demostrar que San Isidoro era cordobés y no hispalense: "Era tan aficionado a Córdoba, que casi le llegaba a pasar de las grandezas de otras ciudades y de los santos y varones insignes de ellas" ${ }^{23}$. El erudito sevillano era consciente de esta rivalidad regional que calificó de "costumbre villana, e hija ordinariamente del odio y la soberbia", y desde el mirador hispalense se permitió exaltar a Cádiz ("lugar antiquísimo y riquísimo") , a Córdoba ("la primera Colonia de ciudadanos Romanos, que en España tuvieron, y que la habitaron los más escogidos de la nobleza Romana") o a Écija ("las más antiguas poblaciones de los Iberos") $)^{24}$.

Durante el siglo XVIII la historiografía introdujo cambios importantes en la interpretación de la historia de España. En sus Anales de la Nación Española (1759) el malagueño Luis José Velázquez, marqués de Valdeflores, revisó la cronología de la historia antigua y planteó que los tartesios habían sido los primeros fenicios establecidos en la península, además de afirmar que Andalucía eran los cuatro reinos. En la misma línea, los cordobeses Pedro y Rafael Rodríguez Mohedano en su Historia literaria de España (12 volúmenes, 1761-1791) defendieron la preeminencia cultural andaluza en el marco español y europeo, como consecuencia de la presencia fenicia y de la romanización. Las invasiones habían sido más positivas, los pueblos de fuera habían aportado más de lo que habían quitado. La evemerización de Gargoris, Habis y Hércules facilitaban aún más la difusión de este enfoque que reivindicaba el papel de los fenicios en la construcción de la civilización española desde Andalucía ${ }^{25}$. Pero para los hermanos Mohedano el referente imprescindible para la renovación de España y de Andalucía era el mundo romano de la Bética. Para el onubense Antonio Jacobo del Barco la Bética era

\section{Ibid., p. 57.}

22 Un detenido análisis en la excelente y gaditana introducción de Arturo Morgado a DE LA CONCEPCIÓN, fray Jerónimo: Emporio de el Orbe, Cádiz, Universidad-Ayuntamiento, 2002, pp. XI-XXIII, cita t. I, p. 62

23 Cit. KAGAN, Richard L.: op. cit., p. 55.

24 CARO, Rodrigo: Antigüedades y Principado de la Ilustríssima Ciudad de Sevila y Chorografía de su convento jurídico, Sevilla, 1634, fols. 71 y 72 (ed. facsímil, Sevilla, Alfar, 1998).

25 Un detallado análisis en WULFF, Fernando: Las esencias patrias. Historiografía e historia antigua en la construcción de la identidad española (siglos XVI-XX), Barcelona, Crítica, 2003, pp. 76-84; y en ÁLVAREZ MARTÍ-AGUILAR, M.: op. cit., pp. 35-45. 
el ejemplo a seguir si se buscaba una recuperación general de la agricultura, comercio e industria que impidiese "que engorden otros cuerpos políticos con nuestra substancia y mejoren con lo que nos sangran. En una palabra: que hagamos ahora los españoles de Andalucía lo que hacían los turdetanos o béticos". Pero con una precisión clara: "Yo no propongo el ejemplo de unos españoles gentiles a unos españoles católicos. Sí exhorto a que seamos laboriosos, constantes, frugales, como lo fueron ellos" ${ }^{26}$. No eran comentarios aislados. En Andalucía tuvo un papel decisivo la Academia Sevillana de Buenas Letras, fundada en 1751. Desde esta institución se incentivaron las investigaciones de los orígenes históricos y de la geografía de Andalucía, de sus inscripciones, medallas y monedas antiguas. Eruditos como Cándido María Trigueros, Sebastián Antonio de Cortés, Antonio Jacobo del Barco, Francisco de Bruna o Ignacio Leirens, y ya en el siglo XIX, Justino Matute, Amador y Demetrio de los Ríos o Ceán Bermúdez dedicaron numerosas memorias y estudios sobre la Bética romana ${ }^{27}$. El romanismo pesaba más que el indigenismo.

A fines del siglo XVIII la generación de los Jovellanos, Martínez Marina o Forner cuestionaron esta historia antigua de los ilustrados, y plantearon un nuevo tipo de Historia de España institucional que arrancaba con el Estado visigodo. Y será, paradójicamente, en este contexto de rechazo patriótico de los "yugos extranjeros", cuando la Bética -consecuencia de la invasión romana- cuaje definitivamente como el espacio histórico legitimador de Andalucía, unidad territorial y cultural de los cuatros reinos.

\section{La geografía y la cartografía: realidad y ficción}

Las primeras y breves descripciones conocidas de la Península Ibérica fueron las de Ptolomeo, Estrabón, Plinio el Viejo y Pomponio Mela; escritas en la Antigüedad, circularon ampliamente en la época medieval. El renacimiento de la geografía en la Italia del siglo XV, con la recuperación de la Geografía de Ptolomeo (s. II) como incentivo, significó la difusión de un género que combinaba historia antigua y la descripción geográfica. La Historia Hispánica (1470) de Sánchez Arévalo, el Paralipomenon Hispaniae Libri X de Joan Margarit (m.XV) y, sobre todo, el De laudibus hispaniae (c.1496) de Lucio Marineo Sículo abrieron el camino a la nueva geografía humanista en España. El mejor heredero de esta recuperación de la geografía fue Pedro de Medina con su Libro de las grandezas y cosas memorables de España $(1548)^{28}$. Cosmógrafo de la Casa de Contratación, Medina fue acusado de plagio por el cronista Florián de Ocampo. A pesar de la certeza de dicha acusación, ese hecho no restó importancia a la obra que terminó por convertirse en un referente para los cartógrafos de los siglos XVI y XVII. Las deficiencias de la obra de Medina y la creciente importancia que el poder político otorgó a la cartografía fueron las razones que posibilitaron un gran proyecto de descripción de España durante el reinado de Felipe II (relaciones topográficas, at-

26 BARCO, Antonio Jacobo del: Retrato natural y político de la Bética, 1762 (BN, ms. 1717, ff. 103v-104r). 27 AGUILAR PIÑAL, Francisco: La Real Academia Sevillana de Buenas Letras en el siglo XVIII, Madrid, CSIC, 1966, pp. 262-265.

28 MEDINA, Pedro de: Libro de grandezas y cosas memorables de España (Sevilla, 1548), en A. González Palencia (ed.), Obras de Pedro de Medina, Madrid, CSIC, 1944, pp. 50-90. 
las, visiones de ciudades,...), que en parte fue fallido ${ }^{29}$. La geografía física derivó en geografía política, y se consolidó como una disciplina indiscutiblemente vinculada a la hegemonía y a la idea de dominio.

Los siglos XVI y XVII fueron una época clave en la historia de la cartografía porque se pusieron los fundamentos del levantamiento cartográfico ${ }^{30}$. Para Andalucía también fue crucial puesto que se elaboraron los principales rasgos de una representación territorial que le otorgaba una cierta coherencia interior y exterior. La realidad geográfica andaluza ya podía ser medida, ordenada y percibida como una unidad diferenciada, y no sólo imaginada. Pedro de Medina, como la gran mayoría de viajeros, tratadistas y cartógrafos de los siglos XVI y XVII, distinguía entre (el) Andalucía y el reino de Granada.

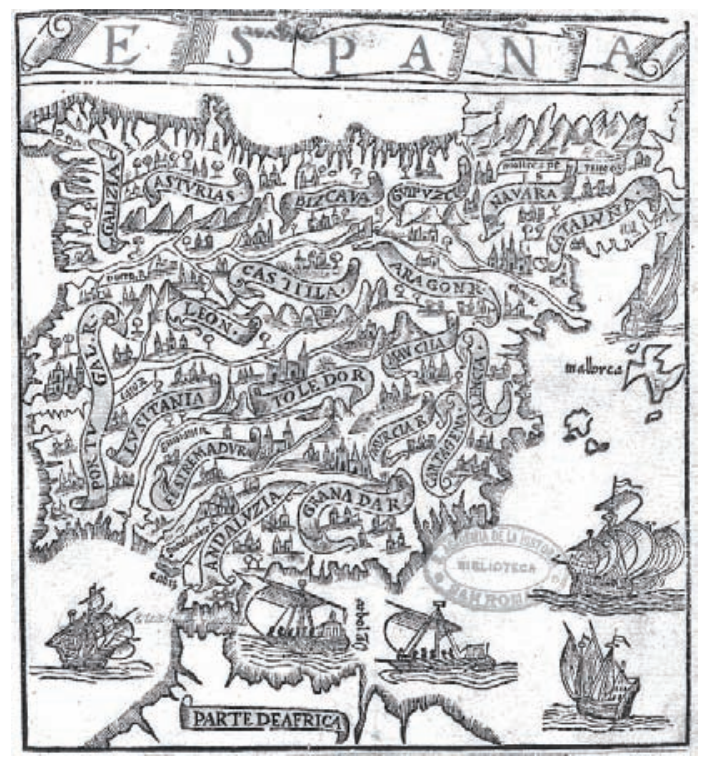

Pedro de Medina, Libro de grandezas y cosas memorables de España, Sevilla, 1548.

Su recorrido comenzaba con la mirada puesta en África desde Gibraltar y concluía en el Guadiana. En este amplio espacio incluía la costa y el interior gaditanos (Algeciras, Tarifa, Conil, Medina Sidonia, Cádiz, Puerto de Santa María, Jerez, Sanlúcar); continuaba con la insularidad andaluza, es decir, las islas Canarias, Madeira (aunque reconocía que era del rey de Portugal) y la Antilla; retornaba a la península por el Guadalquivir y realizaba una extensa descripción de Sevilla y alrededores; seleccionaba las grandes villas de Lebrija, Morón, Martos, y las ciudades de Écija, Antequera, Córdoba, Jaén y Baeza; y terminaba en las villas de Niebla y Palos -con especial mención "al muy notable camino que de ella hicieron por la mar ciertos navegantes". Varios as-

29 Véase KAGAN, Richard: “Arcana Imperii: Mapas, ciencia y poder en la corte de Felipe IV”, en F. Pereda y F. Marías (eds.), El Atlas del Rey Planeta... , pp. 57-61; HERNANDO, Agustín, El mapa de España: siglos $X V$-XVIII, Madrid, CNIG, 1995.

30 BOUZA, Fernando: "Una historia en mapas, una historia de mapas”, en De Mercator a Blaeu. España y la Edad de Oro de la cartografía en las Diecisiete Provincias de los Países Bajos, Barcelona, Nerea, 1995. 
pectos destacan en este recorrido. Las detalladas descripciones de las ciudades y villas bajo la jurisdicción de la Casa de Medina Sidonia se explicaban por los servicios que Medina hacía al Duque. La inclusión en Andalucía de las islas atlánticas se entendía en tanto que habían sido conquistadas desde el sur peninsular y que, durante esos años, ya eran escalas obligadas en los viajes a América. Por último, Medina introdujo un aspecto relevante sobre el cambio en los territorios, siguiendo preceptos aristotélicos; así, en el capítulo XXXIII ("Cómo la mar ha cubierto y descubierto muchas partes de la tierra") justificaba la falta de las islas Afrodiseas frente a Tarifa por las "mudanzas naturales, muy comunes y acostumbradas en el mundo" o la insularidad de Cádiz "que por muy cierto se tiene fue junta y una con la tierra del Andalucía”. De ahí sólo había un paso para entrar de lleno en la geografía imaginaria de las islas. Pertenecía a Andalucía esa isla fantástica que la geografía clásica situaba en los confines de Occidente, y en la que la tradición medieval erudita situaba todos los mirabilia. Medina, convencido de la existencia de la Antilla (Atlántida) cerca de Madeira aunque "ahora no se ve", argüía que su información procedía de un mapa de Ptolomeo dirigido al Papa Urbano, en el cuál se decía:

"Esta isla Antilla, en otro tiempo por los lusitanos fue hallada, más ahora cuando es buscada, no se halla. Hay en ella gentes que hablan la lengua de España, que del rey don Rodrigo postrero de los reyes Godos de España, cuando los Bárbaros en ella entraron, créese que a esta isla huyó. Esta isla tiene un Arzobispo y seis Obispos, donde cada uno tiene ciudad propia, por la cual de muchos fue llamada la isla de las siete ciudades. La gente de ella vive cristianísimamente; tiene abundancia de todos los bienes y riquezas de este mundo"

En la representación y descripción de la Andalucía en el siglo XVII no se hallarán rasgos de insularidad lejana, ni de islas imaginadas. Algunos rasgos, no todos, de la antigüedad mítica se habían cuestionado a lo largo del Quinientos. En sus Diálogos de medallas, inscripciones y otras antigüedades (1587) Antonio Agustín había negado la insularidad de la Atlántida, aunque prefería situarla en España, y en concreto en Gadir $^{31}$.

En el siglo XVII la representación cartográfica restringe e introduce nuevos espacios geográficos stricto sensu andaluces. En el Mapa de Mercator y Hondius de 1606, se superponen diversas jurisdicciones eclesiásticas y señoriales con referencias históricas a pueblos de la antigüedad, se sustrae el Jaén oriental y se suma (con dudas) la Baja Extremadura. Las diócesis eclesiásticas se reducen a tres (hispalense, gaditana y cordobesa). El territorio de Cazorla vinculado al arzobispo de Toledo queda fuera del reino de Jaén; Alcalá la Real pasa al reino de Granada; y Linares, Vílchez o Iznatoraf se enmarcan en La Mancha castellana. El valle de Alcudia se entremezcla con la sierra norte de Sevilla; y la onubense Beturia se sitúa en la campiña gaditana ${ }^{32}$.

31 Véase RALLO, Asunción: Los Libros de Antigüedades en el Siglo de Oro, Málaga, Universidad, 2002, pp. 52 y 68.

32 Andalucía. La imagen cartográfica de la antigüedad a nuestros días, Sevilla, CEA-ICA, 2009, p. 34. 


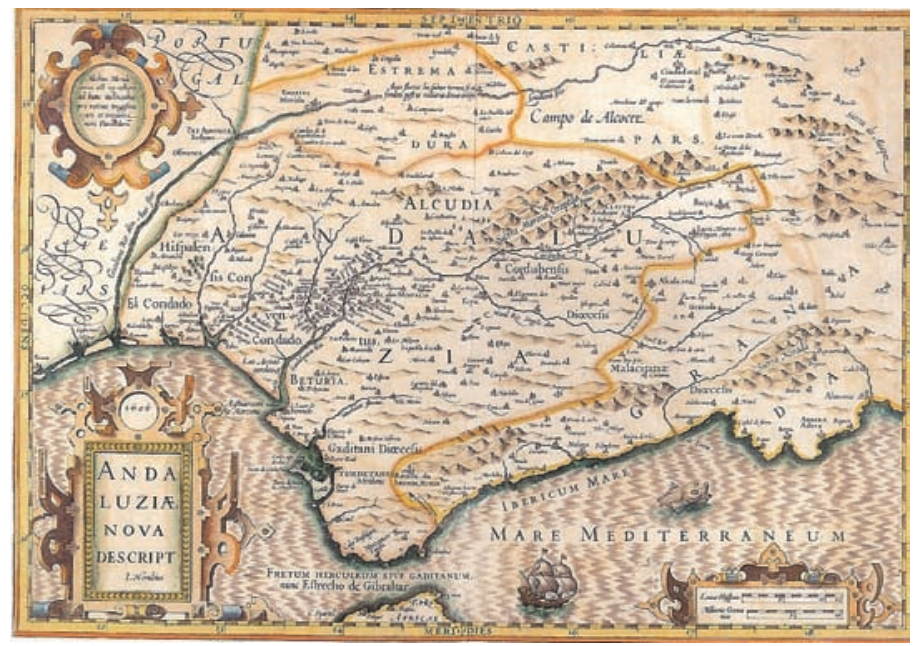

G. Mercator-H. Hondius, Mapa de Andalucía, 1606

En un reciente catálogo se incluye este mapa con el título "Andalucía, al completo" con los siguientes comentarios: "A principios del siglo XVII se publica por fin un mapa de suficiente tamaño y notable rigor cartográfico que abarca la totalidad de la región andaluza". Un comentario poco riguroso que, sin embargo, concluye: "Según la organización vigente hasta el siglo XIX, bajo la denominación de Andalucía se agrupan los antiguos reinos de Sevilla, Córdoba y Jaén que se extienden en torno al valle del Guadalquivir, mientras que el territorio mediterráneo recibe el título de reino de Granada".

En la primera mitad del siglo XVII prevalecía aún la distinción entre Granada y Andalucía, aunque algunos indicios señalan que se estaba iniciando un proceso de aproximación. En la Descripción de España y de las costas y puertos de sus reinos (1634) de Pedro de Texeira sólo se reconocía un reino de Andalucía, dividido entre Sevilla y Córdoba (que incluía también Jaén). Así se muestra en el mapa, aunque sobre el territorio sevillano no aparezca ninguna referencia al término "reino" mientras que sí se explicita en el de Córdoba. El recorrido de Texeira por las costas andaluzas comenzaba en la desembocadura del Guadiana para terminar en Tánger, previo paso por la ría de Huelva, la bahía de Cádiz y barra de Sanlúcar, la bahía de Gibraltar, el estrecho y el puerto de Ceuta.

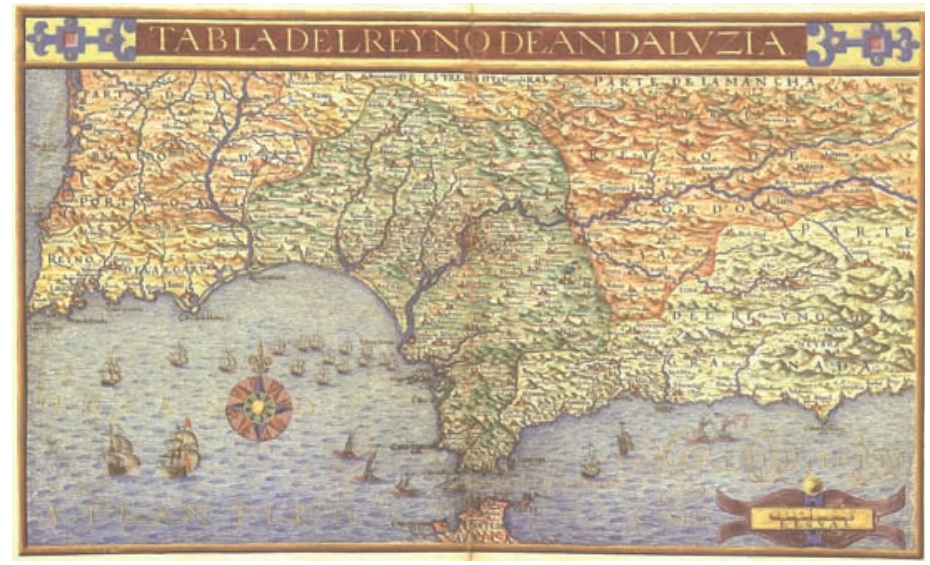

Pedro Texeira, Descripción de España y de las costas y puertos de sus reinos, 1634. 
Pero ni siquiera el recorrido costero le libra de continuas imprecisiones en los límites y leyendas. Así, la confusión se mantiene en la descripción escrita de España y en la representación del reino de Granada. Cuando trata sobre los reinos de España y sus principales ciudades escribe: "El reino de Andalucía tiene en la noble ciudad de Sevilla asistente y audiencia". Y después de referirse a otros reinos, comenta: "El reino de Córdoba a su ciudad Córdoba y en ella su corregidor. El reino de Jaén a la ciudad de Jaén y en ella su corregidor". Texeira no tenía una percepción clara de las grandes divisiones administrativas andaluzas, pues cuando en el mapa del reino de Granada señala sus límites asocia de nuevo Andalucía con el reino de Sevilla (Parte del Reyno de Andaluzía), y lo diferencia del reino de Córdoba (Parte del Reyno de Córdova) y del reino de Jaén (Parte del Reyno de Jaén). Recordemos que, por el contrario, en la Tabla del Reyno de Andaluzía incluía el de Jaén en el de Córdoba.

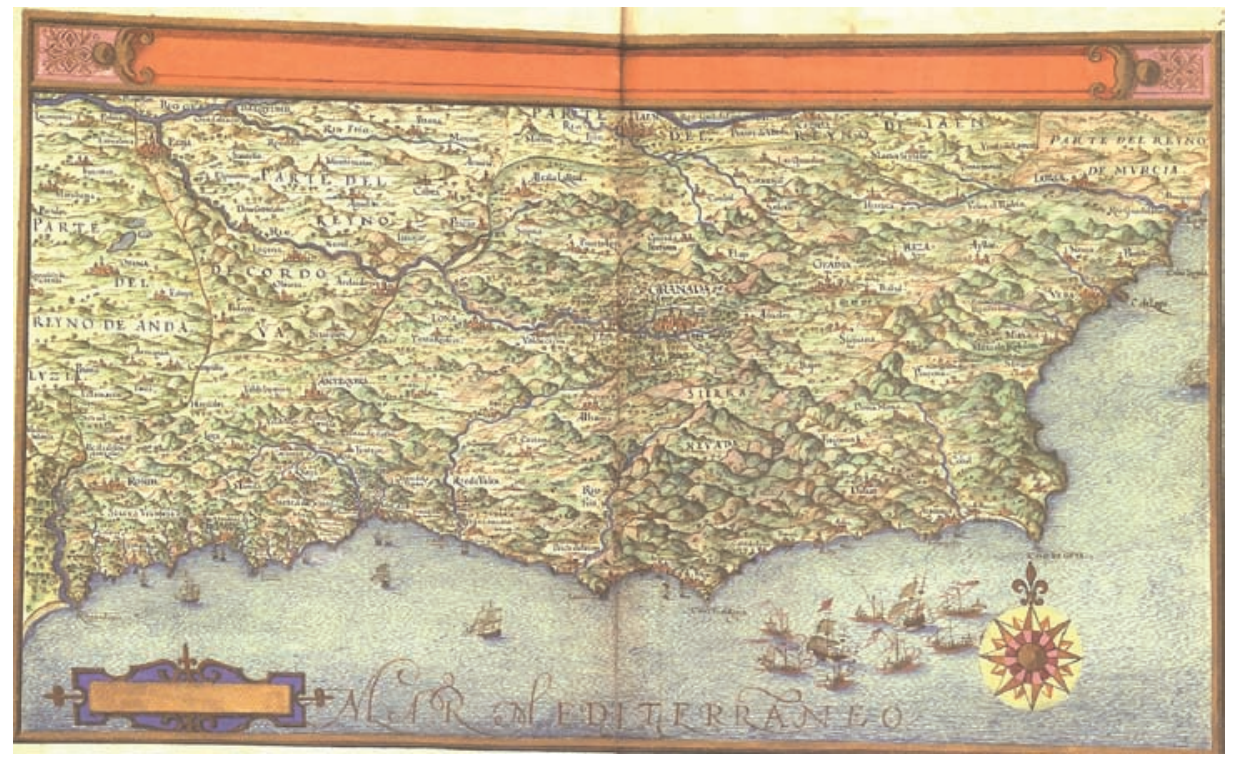

Pedro Texeira, Descripción de España y de las costas y puertos de sus reinos, 1634,

Esta inserción de Jaén en el reino de Córdoba se repite de nuevo en el mapa del Atlas Maior de 1665 de Joan Blaeu, donde Andalucía sigue siendo la suma de los reinos de Sevilla y Córdoba, y tan separada de Granada como de Castilla la Nueva. 


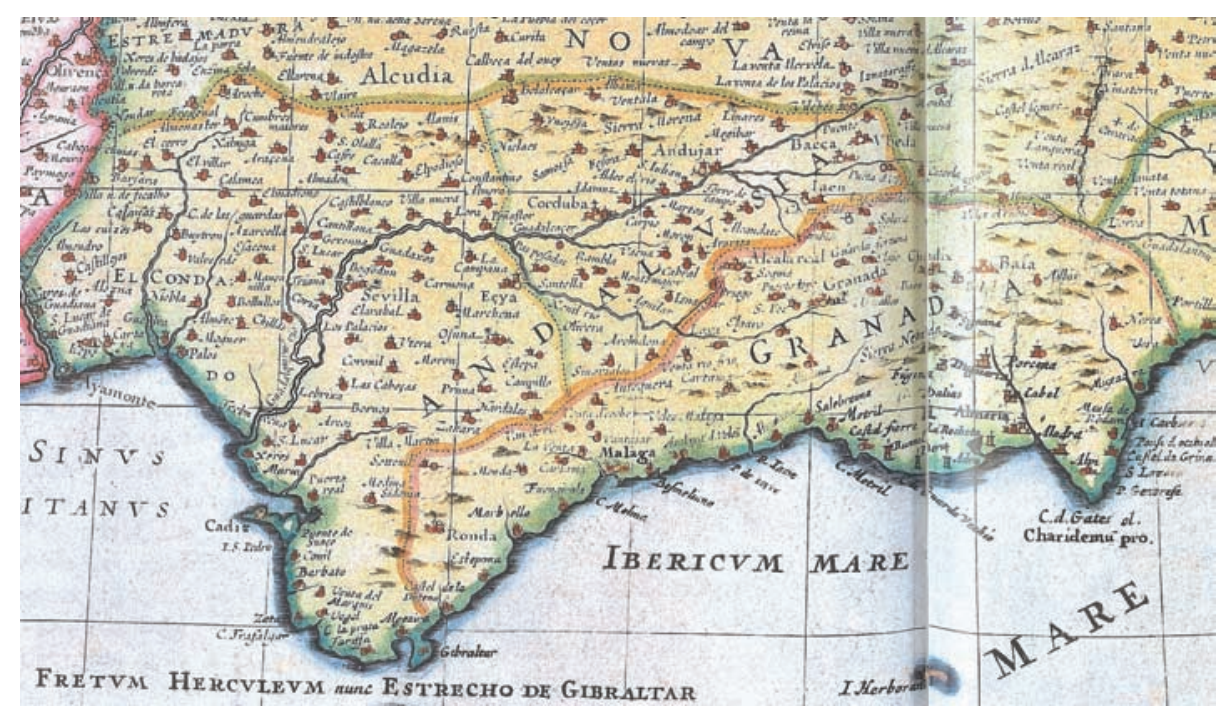

Joan Blaeu, Atlas Maior, $1665^{33}$

Sorprendente es otra versión de esta serie de mapas de la familia Blaeu, donde Málaga es ya andaluza, aunque su diócesis esté en tierras de Granada, en cuyo reino también se incluye Cazorla, Alcalá la Real ${ }^{34}$.

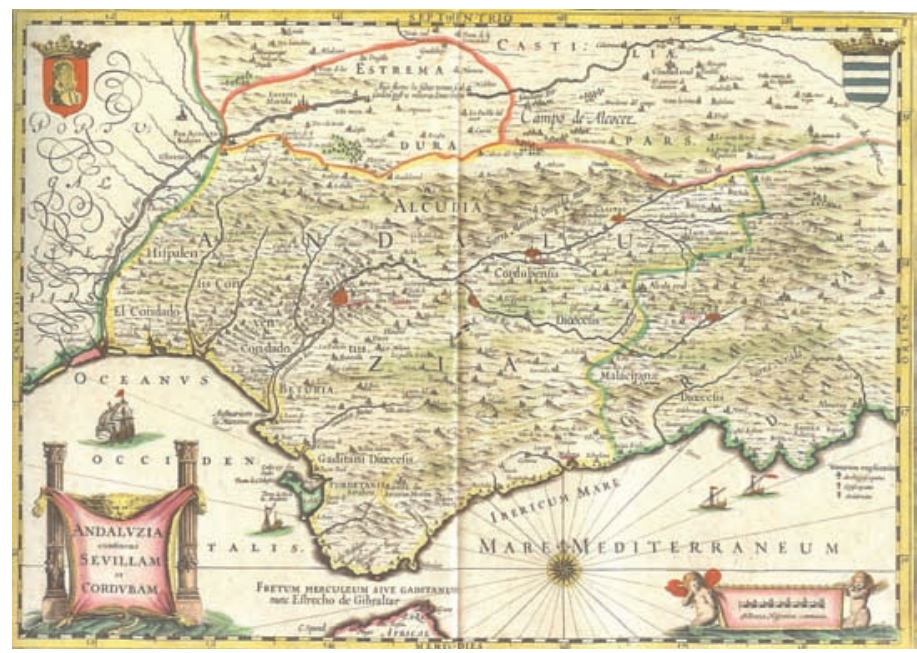

33 En otra versión de este mismo mapa incluido en el catálogo Andalucía. La imagen cartográfica ... p. 43, y con la clásica cartela "Andalucía contiene Sevilla y Córdoba" enmarcada en las columnas de Hércules, se reproduce un mapa donde no se especifican los reinos, pero se distinguen tres territorios (Sevilla, Córdoba y Jaén). Sobre la descripción y mapas de Blaeu véase TASCHEN, Benedikt (dir.), Joan Blaeu, Atlas Maior 1665. Hispania, Portugallia, Africa \& America, Colonia, Taschen, 2006.

34 Obsérvese la superposición de límites jurisdiccionales de las diócesis y arzobispado, y la línea de color amarillo que levemente indica que el territorio malacitano era de una diócesis distinta (Andalucía. La imagen cartográfica ..., p. 45) 
En la gran mayoría de los mapas de la familia Blaeu, la isla de Cádiz comienza a ser delimitada como un espacio independiente (o muy singular) de Andalucía. En el Atlas de 1665 se incluye excepcionalmente un preciso mapa de la bahía. El tráfico comercial con América y Europa hacen que sea el único puerto español representado en dicho atlas; sin embargo, el comentario sobre sus características es más que incompleto: "La principal riqueza de los habitantes de esta isla es la sal que elaboran y la pesca de atunes" 35 .

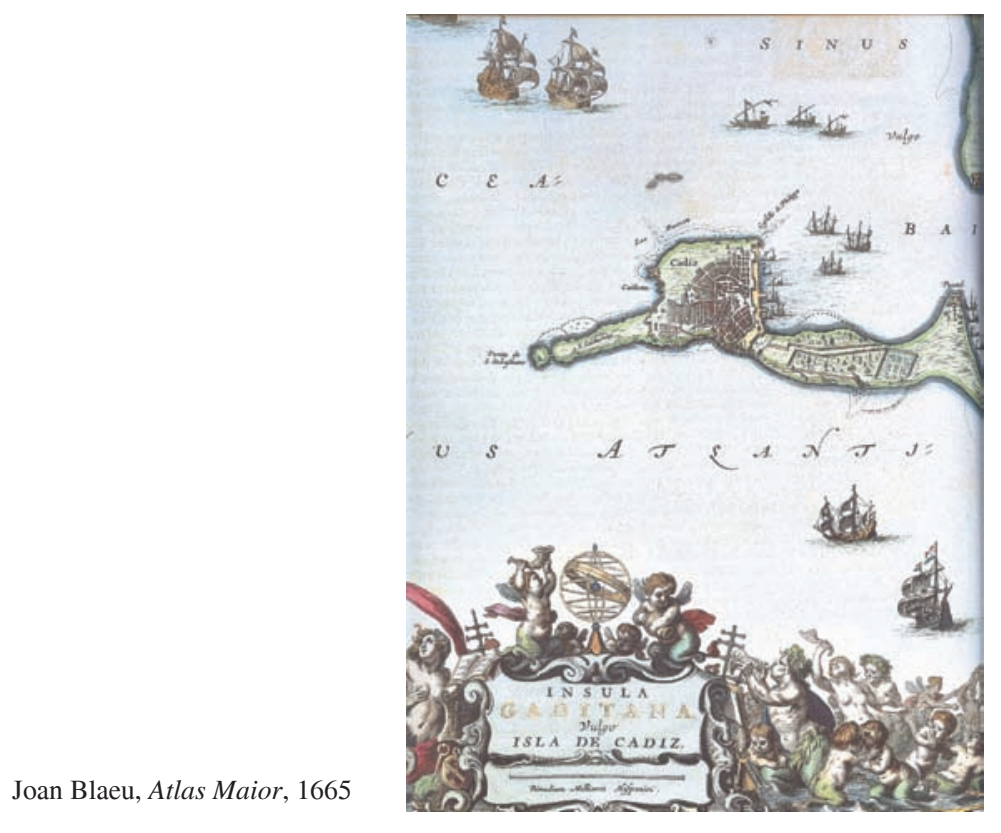

La imagen geográfica de Andalucía era a fines del siglo XVII la misma que se tenía desde hacía cuatro centurias. El viajero francés Jouvin la definía así en 1672: "tiene por límites: en el Septentrion, Castilla; al mediodía, el reino de Granada; al poniente, Portugal y el estrecho de Gibraltar"36. No obstante, a lo largo de esa misma centuria se perciben signos que explicarían la constante imprecisión y /o confusión que hemos referido en la representación cartográfica de Andalucía y del reino de Granada, como espacios diferentes. Es posible que Agustín de Horozco tuviese esa visión del conjunto de Andalucía, cuando hacia 1598 relata como Fernando III "ganó la mayor parte de la Andalucía, la ciudad de Córdoba, Sevilla, Jerez y esta isla de Cádiz con toda su comarca, pasados más de quinientos treinta y cinco años que estaban en poder de los moros"37. O quizás no, y la opinión dominante a comienzos del siglo XVII fuese la expresada por Pedro Espinosa de los Monteros, quien después de relatar las conquistas

35 Joan Blaeu, Atlas Maior 1665..., pp. 25-26.

36 Cit. VEEP, vol. III, p. 646

37 HOROZCO, Agustín de: op. cit., p.200. 
de Alfonso X el Sabio apunta que "Viendo ya libre el Andalucía, determinó de pasar en África, para sujetarla, en satisfacción de lo que los moros habían tenido en España" 38 .

Una definición más clara de los límites de una gran Andalucía los hallamos en Agustín de Tejada a comienzos del siglo XVII: "Es pues España repartida en diversas provincias. La más fértil, rica y abundante de todas es la Andalucía que comienza en Sierra Morena que la divide de Castilla (...) Su latitud es desde esta sierra hasta el mar Mediterráneo; su longitud es desde el mar de Cádiz a la sierra de Filabre que está en el reino de Granada (...) Divídela el estrecho Gibraltar de la antigua y ardiente que ahora llamamos África" 39 . Rodrigo Caro, al comentar en su Chorografía (1634) la posible relación entre la Munda romana y la ciudad de Ronda, recuerda que ésta es "famosa en el Reino de Granada por ser cabeza de una gran serranía, que habitaron moros, y hoy corregimiento y ciudad de las principales de la Andalucía" (f.181v). Ese mismo comentario se recoge en las Antigüedades de Ronda (c.1660) de Macario Fariñas del Corral: "Es una de las principales de el Andalucía, reconócenle por la segunda en el Reino de Granada" ${ }^{40}$.

Para Domínguez Ortiz, el primer paso hacia una visión unitaria de Andalucía se produce con la expulsión de los moriscos en 1610: "Al desaparecer el cuerpo extraño que representaba la minoría morisca ya no había inconveniente en aplicar unos mismos conceptos a las tierras orientales y a las occidentales. Como suele ocurrir, el uso vulgar se adelantó a una administración rutinaria y el nombre de Andalucía y andaluces se aplicó a una y otra parte por igual”. Domínguez Ortiz hallaba indicios de esta convergencia semántica en los conocidos versos de Quevedo: "En Navarra y Aragón / no hay quien tribute ya un real; / Cataluña y Portugal / son de la misma opinión / sólo Castilla y León / y el noble reino Andaluz / llevan a cuesta la cruz" ${ }^{41}$. Para él, al referirse al "noble reino andaluz", se "aludía a los cuatro reinos meridionales de España”. Y añadía dos argumentos más del siglo XVII: “Andaluces eran llamados, sin más distingos, en Salamanca, todos los estudiantes de nuestra región, y a todos sus habitantes se dirigía el elogio tan conocido de Suárez de Figueroa en El Pasagero, donde contrapone una Castilla "huraña y silvestre" a una Andalucía rica y generosa" ${ }^{42}$.

Esta extensión del término Andalucía a todos los reinos del Sur lo hallamos en la documentación, que el propio Domínguez Ortiz recopiló, referente a las protestas acaecidas en la primavera de 1647. En una consulta del Consejo de Castilla se especifica: "Señor.- Con el cuidado que el Consejo ha tenido de los tumultos que se levantaron en

38 ESPINOSA DE LOS MONTEROS, Pedro: Historia y grandezas de la Ciudad de Sevilla. Primera parte (1627), Sevilla, Ayuntamiento, 2009, f. 144v..

39 TEJADA PÁEZ, Agustín de: Discursos históricos antequeranos (1587-1608), ed. A. Rallo, Málaga, Diputación, 2005, vol. I, p. 152. Las cursivas son propuestas de la editora para completar el texto.

40 Cita tomada de REINOSO, Fernando: Antigüedades de Ronda (BN, ms, 1361, f.1). Se trata de una atribución errónea, según se recoge en CUEVAS, Cristóbal (dir.), Diccionario de escritores de Málaga y su provincia. Madrid, Castalia, 2002, pp. 265-266, donde se le asigna al historiador y anticuario rondeño Macario Fariñas. Sobre sus relaciones con Caro véase ABASCAL, Juan Manuel y CEBRIÁN, Rosario: Memoria sobre antigüedades de la Real Academia de la Historia, Madrid, RAH, 2005, p. 203.

41 Cit. EGIDO, Teófanes (ed.): Sátiras políticas de la España Moderna, Madrid, Alianza, 1973, p. 119.

42 DOMÍNGUEZ ORTIZ, Antonio: La identidad de Andalucía, Granada, Universidad, 1976, p. 28. 
algunos lugares del Andalucía parece se ha conseguido la quietud que se deseaba, ejecutando en los más culpados los castigos que parecieron convenientes, y particularmente en la ciudad de Alhama, que era lo más peligroso"43. "Andalucía ladra; no sé si morderá", este comentario circulaba por Madrid en 1648, y es plausible que se refiriese al conjunto de los cuatro reinos y a la convulsa situación que estaban atravesando ${ }^{44}$. Pero durante esos años es habitual hallar comentarios que distinguen entre una y otra parte. Por ejemplo, en las memorias sevillanas de 1638 al recoger noticias sobre los protestas antifiscales portuguesas el escribano anotó: "De toda la Andalucía alta y baja vinieron compañías de infantería y caballería, y de Granada y Murcia. Juntóse toda esa gente para castigar unos alborotos que hubo en Portugal por una nueva imposición que pedía su majestad"45.

A comienzos del siglo XVIII la percepción unitaria estuvo más extendida, aunque con matices respecto a su historia. En un opúsculo catalán anónimo (c. 1700) se realizaba un interesante comentario sobre la fidelidad de los andaluces respecto a la Corona, frente a el incuestionable austracismo de los catalanes. Roca el soldado catalán le recuerda a Núñez (andaluz) el pasado castellano e islámico de Andalucía en estos términos:

"Roca: (...) en los casos primeros de los castellanos [guerra civil 1464-1469], los andaluces tuvisteis tanta parte como ellos, menos los granadinos, que aún estaba aquello ocupado de los moros; pero cuando ya Granada estaba en su grandeza y había mucho tiempo que estaba en manos de los cristianos, fue el sayo que en tiempo de Felipe IV siendo entonces Granada la cabeza de toda la Andalucía levantaron por Rey a un tintorero de paños, sino que lo supieron algunos realistas y se lo disuadieron, y él desistió. Mas por parte de los andaluces ya estaba hecho el Rey al cual llamaron Rey de trapos, y así sois rebeldes trapistas.

Núñez: Vosotros no hicisteis Rey al Francés

Roca: Es verdad, pero era un Rey Grande, que casa con hijas de España, y al contrario, mas no Rey de trapos.

Núñez: Ya viste con lo de David cuán inculpable era, también Andalucía lo hizo obligada de los insoportables pechos.

Roca: Ya veo yo que son grandes, pero amigo paciencia que esa tierra la quitaron los Reyes de Castilla a los moros con sus armas y dinero, y así se pudo quedar con el poder absoluto de poner y quitar pechos; y así o irse o pagar. Aunque no niego fuera bien los moderaran, para que todos pudieran vivir, y así amigo Núñez concluyo, que antes de quitarme a mí la paja, te limpies bien los ojos y apartes la biga"46.

43 AHN, Consejos, 7.160-1. DOMÍNGUEZ ORTIZ, Antonio: Alteraciones andaluzas, Madrid, Narcea, 1972, doc. 1.

44 GELABERT, Juan Eloy: Castilla convulsa (1631-1652), Madrid, Marcial Pons, 2001, p. 304.

45 Cit. MORALES PADRÓN, Francisco (ed.): Memorias de Sevilla (Noticias sobre el siglo XVII), Córdoba, Monte de Piedad y Caja de Ahorros de Córdoba, 198, p. 82.

46 Luz de la verdad. Preguntas y respuestas a favor de Cataluña y sus hijos, originada de una disputa habida entre cinco soldados de a caballo de España. Respuestas de Juan Roca, uno de los mismos propugnantes, Biblioteca Universitaria de Barcelona, ms. 146, ff. 73-74. Otros ejemplares en Biblioteca de Catalunya, Fullets Bonsoms, 96 y 9316. Pudiera ser la rebelión de los moriscos, pues la gente del Albaicín, cuando se alzaron en 1568 propusieron como rey morisco a Farax abén Farax, tintorero y comerciante de arrebol, en oposición a Abén Humeya (SÁNCHEZ RAMOS, Valeriano: "La guerra dentro de la guerra: los bandos moriscos en el alzamiento de las Alpujarras", en VII Simposio Internacional de Mudejarismo, Teruel, Centro de Estudios Mudejares, 1999, pp. 507-522). 
Se ha afirmado que fue a mediados del siglo XVIII cuando se difundió definitivamente una imagen unitaria de Andalucía, y que en este paso fue clave la obra del geógrafo y jesuita granadino Pedro Murillo Velarde. Sin embargo, existe un antecedente que debió inspirar a Murillo. Se trata de Rodrigo Méndez Silva quien en 1675 aportaba la razón principal de porqué podía hablarse de una única Andalucía. Al describir la Provincia de Andalucía señalaba que estaba compuesta por tres reinos, pero "si citamos toda la Bética, son cuatro con el de Granada”. Su propuesta no le debía convencer porque el siguiente capítulo estaba dedicado a la descripción del reino de Granada: "llamado así por su cabeza y Ciudad Metrópoli, es uno de los cuatro referidos también de la Bética" que tenía "a Occidente Andalucía" anteriores descripciones geográficas fue la inserción de un capítulo (XII) en el que delimitaba Andalucía desde la raya con Portugal hasta la costa almeriense, su argumento no era otro que reagrupar el territorio del sur de la Bética: "Hoy comprende los cuatro Reinos de Granada, Sevilla, Córdoba y Jaén, y se divide en Andalucía Alta, que es Granada, y Baja, que es lo restante. Muchas veces se toma el Reino de Granada por cosa distinta del Andalucía, por ser Reino tan principal". El siguiente capítulo está dedicado al Reino de Granada y comienza así: "El primero, y principal Reino de Andalucía es el de Granada, que se llama Andalucía la Alta”. Pero el capítulo XIV comienza con esta contradictoria afirmación: "Andalucía se entiende especialmente por los Reinos de Sevilla, Córdoba y Jaén"48. La visión unitaria ya la percibían y transmitían algunos viajeros en el último cuarto del siglo XVIII, como Jean François Peyron (1777-78) que afirmó que Andalucía se dividía en alta y baja; siendo Granada la capital de la primera y Sevilla de la segunda ${ }^{49}$.

Mientras la descripción del espacio andaluz tendía hacia la unidad, en las representaciones cartográficas de la segunda mitad del siglo XVIII se insistía aún en los límites de aquella frontera bajo-medieval ${ }^{50}$. El gran cartógrafo y geógrafo Tomás López no empleó el término Andalucía en los mapas generales de 1770 y 1788, pero sí lo hizo en una aclaración escrita en la cartela inferior al afirmar que la provincia de Andalucía estaba compuesta por Sevilla, Córdoba y Jaén ${ }^{51}$.

47 MÉNDEZ DE SILVA, Rodrigo: Población general de España, Madrid, Roque Rico, 1675, ff. 67 y 91. 48 MURILLO VELARDE, Pedro: Geographia historica : donde se describen los reynos provincias, ciudades, fortalezas ..., Madrid, Gabriel Ramírez, 1752.

49 PEYRON, J.F.. Nuevo viaje en España o Cuadro del estado actual de la Monarquía, Ginebra , 1780 (VEEP, vol. 5, pp..237-441). Sobre el cambio de percepción de los viajeros del siglo XVIII véase MARCHENA, Manuel J.: La imagen geográfica de Andalucía, Sevilla, Rd editores, 2007, pp. 93-123.

50 Véase la rica recopilación de mapas históricos de Andalucía en la sección "biblioteca cartográfica" en http://www.juntadeandalucia.es/cultura/bibliotecavirtualandalucia.

51 LÓPEZ GÓMEZ, Antonio y MANSO PORTO, Carmen: Cartografía del siglo XVIII.Tomás López en la Real Academia de la Historia, Madrid, RAH, 2006, mapa nº 270. 


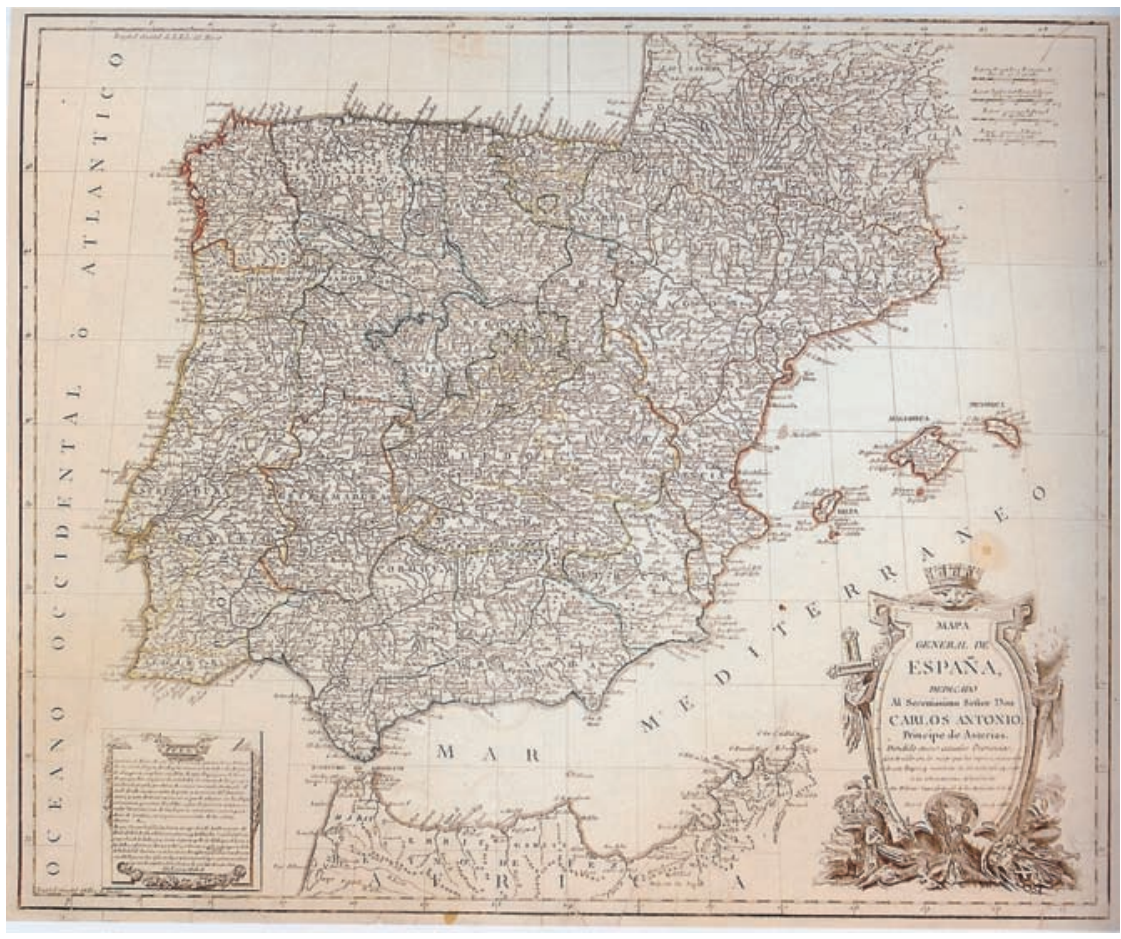

La división persistía en los mapas de comienzos del siglo XIX. Hacia 1807 el viajero norteamericano Robert Semple elaboraba un mapa de las carreras de postas de España, y en él todavía se señalaban Andalucía y Granada como espacios no coincidentes $^{52}$. La reforma territorial bajo José I impuso 42 prefecturas, de las cuales cinco correspondían a los territorios del sur, ahora con denominación hidrográfica: Genil, con capital en Granada (provincias de Almería y Granada); Guadalete, con capital en Jerez (provincia de Cádiz); Guadalquivir Alto, con capital en Jaén (provincia de Jaén); Guadalquivir Bajo, con capital en Sevilla (provincias de Huelva y Sevilla); y Guadalquivir y Guadajoz, con capital en Córdoba (provincia de Córdoba). El proyecto liberal de 1822, que no llegó a aplicarse, fue el primero en reconocer a Andalucía como región, con ocho provincias.

La cartografía no dejará constancia de la unidad del espacio andaluz hasta el mapa de 1830 de Tomás Mauricio López, donde los cuatro reinos se denominan ya Andalucía $a^{53}$.

52 PLAZA, Rocío: Los caminos de Andalucía. Memoria de los viajeros del siglo XVIII, Sevilla, Universidad, 2009, p. 40.

53 LÓPEZ GÓMEZ, A. y MANSO PORTO, C.: op. cit., mapa nº 271. 


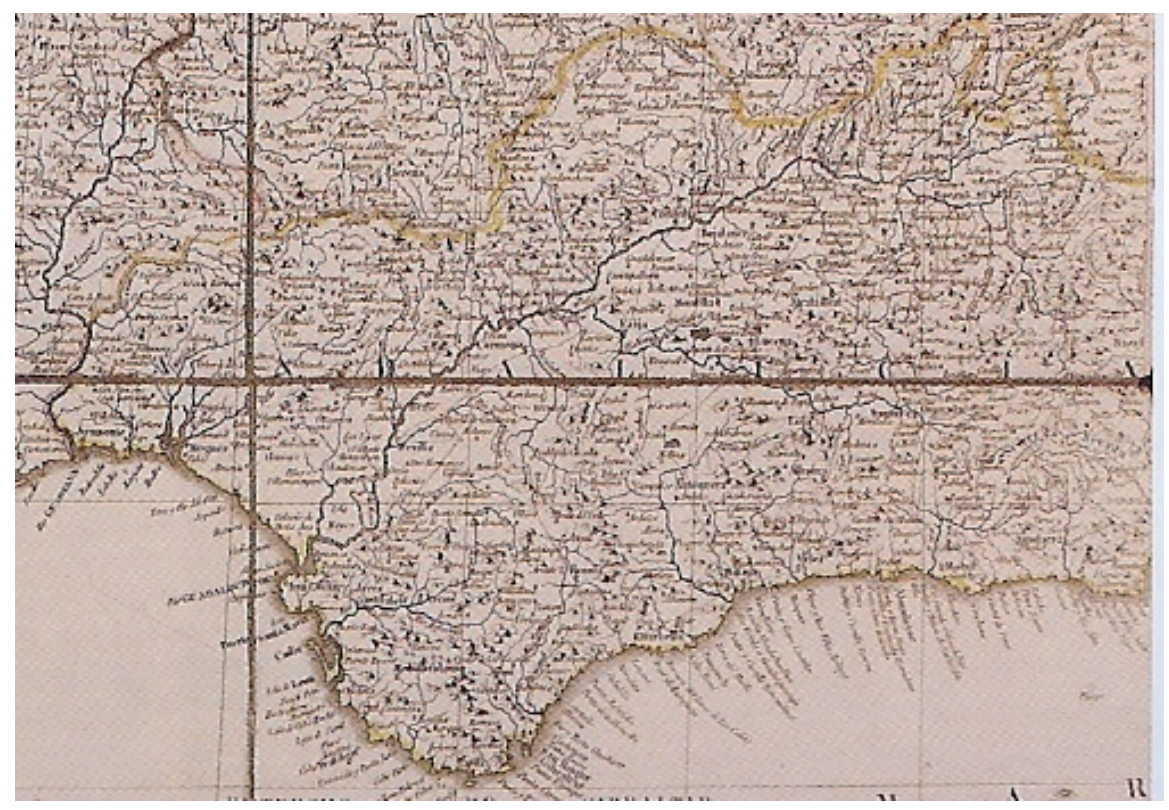

La división territorial que estableció el granadino Javier de Burgos en 1833 consolidó definitivamente esta representación unitaria, sin mayor peso administrativo que la agrupación regional de las ocho provincias. Pero los débiles fundamentos de esta división se pusieron de manifiesto en los sucesivos proyectos de reforma territorial que se elaboraron durante el siglo XIX. En 1847 el decreto de Patricio de la Escosura, suspendido ese mismo año, separó Granada de Andalucía, aunque con una variante: Jaén dejaba la Andalucía fernandina y pasaba ahora a la región de Granada. En el Proyecto de Constitución Federal de la I República (1873) se retomaba la división Escosura para el caso andaluz. Otro intento de reforma fue el propuesto en 1884 por Segismundo Moret, la separación se mantenía igual pero con un cambio en la denominación, en lugar de llamarse Andalucía la región de las cuatro provincias (Cádiz, Sevilla, Córdoba y Huelva) se iba a nombrar como Sevilla. En el proyecto de 1891 de Sánchez de Toca continuaba esta separación y este cambio de denominación. Durante la II República otro proyecto fallido incluía en Andalucía a Badajoz y restaba a Almería ${ }^{54}$. Se podría concluir que Andalucía no tenía peso histórico para ser valorada como un conjunto regional, situación similar se daba con las Castillas, Valencia y Aragón. Pero también se debe advertir que estos criterios administrativos racionales se intentaron imponer sin tener en cuenta razones de cierta afinidad o trayectoria históricas. Argumentos que sí plantearon las elites culturales andaluzas en los siglos XVII y XVIII.

54 LAÍNZ, Juan: “Adiós, España”. Verdad y mentira de los nacionalismos, Madrid, Encuentro, 2004, pp. 603-605. 


\section{A modo de conclusión: El (re)encuentro bético}

La memoria de la invasión musulmana no era fácilmente integrable en el mundo cultural y religioso del catolicismo. Pero al ignorar la Andalucía musulmana, los eruditos del siglo XVI y XVII tuvieron enormes dificultades para entender cuáles eran los límites y los fundamentos de la Andalucía de los tres reinos. Les unía a la parte granadina su pasado bético y su cristianismo, que en la ciudad de la Alhambra estaba en sus propios orígenes, pues era exaltada como la capital del cristianismo primitivo peninsu$1 a r^{55}$. Aunque, a diferencia de la parte occidental, Granada arrastraba la duda sobre su fundación musulmana o judía. Roma era útil para todo, para limpiar la obsesión por la pureza de sangre e, incluso, para exponerse en todos los órdenes arquitectónicos. Pero la identificación con Roma tenía unos límites: era símbolo de paganismo y, además, ya había sido recuperada por los italianos. Por esas razones, a la reivindicación romana las elites culturales granadinas tuvieron que anteponer unos orígenes cristianos. Bermúdez de Pedraza ( Antigüedad y excelencias de Granada, 1608; Historia eclesiástica de Granada, 1638) y Antolínez de Burgos (Historia eclesiástica de Granada, 1696) hicieron la mayor justificación de la antigüedad cristiana y el martirio de San Cecilio, prolongada en el tiempo con el conocido fraude arqueológico del canónigo Juan de Flores ${ }^{56}$. Atrás quedarían la evocaciones de lo andalusí, los intentos fallidos de reivindicar una cultura mixta, cuyas raíces llevaban hasta la crónica del moro Rasis ${ }^{57}$. La invención de la protohistoria local -en la que se incluyeron las conocidas falsificaciones del Sacromonte y distintas obras maurófilas- fueron, según la gran mayoría de los historiadores, una maniobra entre cristianos nuevos - moriscos, quizás de doble vida- para difundir una Granada habitada en fechas muy tempranas por árabes que abrazaron el cristianismo de mano de los primeros predicadores llegados a la Península ${ }^{58}$. Hubo que esperar al retorno de la maurofilia y lo orientalizante a fines del XVIII y, principalmente, durante los siglos XIX y XX, para que sobre esa base pudieran establecerse nuevos lazos entre andaluces de un lado y de otro ${ }^{59}$.

La frontera mental no desapareció cuando se culminó la conquista del reino nazarí. Permaneció, aunque sin el componente bélico y, después de la expulsión de los moriscos, sin el elemento étnico diferenciador. Los intercambios económicos, los

55 MALPICA, Antonio: "De nuevo sobre los orígenes de Granada", en J. A. González Alcantud y R. G. Peinado Santaella (eds.), Granada la andaluza, Granada, Universidad, 2008, p. 21.

56 SOTOMAYOR, Manuel : Don Juan de Flores y Oddouz, pícaro y mártir. Cultura y picaresca en la Granada de la Ilustración, Granada, Universidad, 2007.

57 CATALÁN, Diego y ANDRÉS, Ma Soledad de : Crónica del Moro Rasis., Madrid, Gredos, 1975.

58 Entre la numerosa bibliografía véase BARRIOS, Manuel y GARCÍA ARENAL, Mercedes (eds.), ¿La historia inventada? : los libros plúmbeos y el legado sacromontano, Granada, Universidad, 2008 y Los plomos del Sacromonte : invención y tesoro, Valencia, Universidad, 2006.

59 Véanse los diferentes trabajos incluidos en GONZÁLEZ ALCANTUD, José Antonio y PEINADO SANTAELLA (eds.), Granada la andaluza.... Elaborados con el objetivo de exponer los finos hilos que unen a Granada y, en mucha menor medida, a Sevilla con la región andaluza, porque según los editores "Andalucía es, se infiere, tierra de promisión por la que circulan ríos de hidromiel simbólica. Pero esta misma Andalucíadeseo ha sido también negación de sí. La aspiración a definir su historia de una manera prístina ha encontrado obstáculos insalvables en sus ciudades. La enemistad local, tan enraizada en todas las culturas, tiene entre nosotros una expresión muy marcada, que ha truncado frecuentemente la aspiración colectiva a ser" (p. 7). 
movimientos demográficos y las transferencias culturales culminaron un proceso de formación de los reinos del sur de España como un espacio con elementos culturales comunes. Sin embargo, durante los siglos XVI y XVII la frontera persistió -como hemos visto- por la herencia fernandina del siglo XIII y sus recuperados vínculos con la romanización de la Bética, frente a la tardía conquista catolizadora del reino infiel en 1492. Dos espacios con representaciones patrimoniales dinásticas distintas.

El colectivo andaluz (occidental), al que también podían incorporarse los granadinos como sugería Tejada Páez, tenían ancestros comunes (bíblicos, pre-romanos y romanos), tenían la memoria de un pasado tartésico y de una época de gran esplendor cultural en tiempo de la Bética romana, además de un elemento religioso común a todos los españoles: el símbolo de la fe. Pero el discurso historicista de estas elites chocaba con los vestigios del dominio musulmán y con la memoria de la guerra, a la que debían recurrir para legitimarse tantas familias nobles que, presuntamente, habían estado al servicio de los reyes cristianos en la conquista.

La cuestión clave, difícil de responder, es cuándo la frontera dejó de ser antes de la reorganización provincial de 1833. Fueron las múltiples jurisdicciones -a veces superpuestas, otras enfrentadas- las que facilitaron la conformación de un espacio único en el sur de España, con peculiaridades comunes: la fe, la nobleza y, enfrente, África, memoria de la ocupación infiel, paréntesis entre la Bética romana, el estado visigodo y la Monarquía católica. La línea tan fronteriza como porosa, separaba dos religiones, dos visiones del mundo ${ }^{60}$. Aunque Hércules continuaba siendo el símbolo de las dos orillas, de la proyección mítica de la cultura occidental hacia el África infiel, la única comunidad imaginada era el colectivo religioso cristiano.

Este sentido providencial lo insertaron las elites intelectuales andaluzas en un rompecabezas identitario localista y regional. La herencia inmaterial, legitimadora de un pasado y no de otro, fue administrada desde los poderes locales, desde los linajes y sus referencias dinásticas. Durante los siglos XVI, XVII y XVIII -aunque como hemos visto con matices importantes-, el principal vínculo con España se construyó mediante la recuperación de la antigüedad clásica y la legitimación de la conquista cristiana.

Cuando esta débil frontera histórica desapareció por imperativo legal en 1833, el tránsito hacia un espacio único andaluz ya se había hecho desde la geografía y la historia. Fue en el mundo cartográfico donde más tiempo se tardó en dejar constancia de este cambio hasta pocos años antes de la sanción administrativa, los ritmos fueron distintos. Este proceso no implicó una conciencia de identidad colectiva andaluza, sino una percepción de elementos históricos y culturales singulares y diferenciados en el conjunto de la identidad española.

Es evidente que en este análisis de la construcción y permanencia de una frontera no se parte del enfoque Estado-nación o de la soberanía como argumento ${ }^{61}$. Es

60 BUNES IBARRA, Miguel Ángel de: "El orientalismo español de la edad moderna: la fijación de los mitos descriptivos", en J. A. González Alcantud (ed.), El orientalismo desde el Sur, Rubí, Anthropos, 2006, pp. 37-53.

61 En la diversidad terminológica del concepto frontera, como plantea Thomas K. Schippers para el caso anglosajón ("La frontière dans l'imaginaire identitaire en Europe", Frontières, París, CTHS, 2002, pp. 7986), cabe advertir fronteras mentales desde la casa al Estado, pasando por todos los niveles intermedios territoriales o no (familia, pueblo, comarca, provincia, reino..). 
importante recordar que Andalucía se convirtió, sin pretenderlo -sin reivindicación imperalista alguna- en una región que amplió su territorio, en perjuicio de la desmembrada Castilla y en despecho del neocolonialismo onírico de los nacionalismos vascos y catalán. Andalucía no necesitó de ninguna tribu de ideólogos nacional-regionalistas para ampliar su territorio o, según se mire, para incluir en él dos espacios con trayectorias históricas tan singulares como convergentes. Eso sí, para los coetáneos de aquel proceso, aquellas tierras habían sido béticas antes que musulmanas. Los anticuarios y arqueólogos andaluces pensaban en términos béticos al reconstruir los orígenes y establecer los límites de su provincia, el goticismo quedaba relegado a la primera unidad política de España porque, a fin de cuentas, Andalucía había sido, ante todo, una gran civilización cultural no un Estado. 
